\title{
Effect of mucin and glucose on proteolytic and glycosidic activities of Streptococcus oralis
}

\author{
A. M. RAFAY, K. A. HOMER* and D. BEIGHTON* \\ Department of Medical Microbiology, London Hospital Medical College, Turner Street, London E1 2AD and \\ * Joint Microbiology Research Unit, Faculty of Clinical Dentistry, King's College School of Medicine and \\ Dentistry, Caldecot Road, Denmark Hill, London SE5 9RW
}

\begin{abstract}
The production of glycosidase and protease activities, which may play a role in the degradation of human glycoproteins, by Streptococcus oralis strains isolated from endocarditis, septicaemia or the oral cavity was investigated with a range of fluorogenic substrates. The $\mathrm{pH}$ optima of the proteases ranged from 6.0 to 9.3 and the $\mathrm{pH}$ optima for the glycosidases were lower (4.5-6.0), although the $\mathrm{pH}$ range over which both groups of enzymes acted was broad. Growth in a minimal medium supplemented with glucose resulted in repression of glycosidase activities and elevated proteolytic activity. Bacteria from cultures supplemented with porcine gastric mucin (PGM), a model glycoprotein, exhibited higher levels of glycosidase activity, while proteolytic activity was suppressed and glycoprotein-derived monosaccharides were transported at significantly higher rates than those observed for cells grown in media with glucose. PGM-derived cells also exhibited high levels of $\mathrm{N}$-acetylneuraminate pyruvate-lyase, the first intracellular enzyme in the pathway of sialic acid catabolism. Taken together, these data indicate that $S$. oralis strains produce a range of proteolytic and glycosidic enzymes that may play a role in the degradation of host-derived glycoproteins.
\end{abstract}

\section{Introduction}

Viridans streptococci form a significant part of the normal flora of the human oral cavity [1] and are associated with systemic diseases that include infective endocarditis, septicaemia and deep-seated abscesses in liver and brain. In the pre-antibiotic era streptococci, and especially the viridans streptococci, accounted for $>80 \%$ of cases of infective endocarditis. Streptococci now account for about half of all cases of infective endocarditis and of these $30-40 \%$ are caused by viridans streptococci [2-4]. Detailed microbiological studies of the viridans streptococci isolated from infective endocarditis have indicated that the predominant species include Streptococcus oralis and $S$. sanguis, with other species such as $S$. mitis, $S$. salivarius and $S$. mutans being isolated less frequently $[4,5]$.

In-vitro observations and studies in experimental animals have suggested that the development of infective endocarditis requires the simultaneous occurrence of several independent events [5]. These include alteration of the surface of the cardiac valve which

Received 12 May 1995; accepted 23 Oct. 1995.

Corresponding author: Dr A. M. Rafay. may be the result of local or systemic stresses, including blood turbulence or inflammation after rheumatic fever or infarction $[6,7]$. These endothelial alterations result in the deposition of platelets and fibrin to form non-bacterial thrombotic vegetations (NBTV). For bacteria to colonise cardiac tissue they must first reach the NBTV, adhere and then replicate. The adherent bacteria are rapidly covered with a sheath of fibrin and platelets to produce an environment that may be conducive to bacterial multiplication, provided that the bacteria are resistant to the platelet-derived antibacterial factors produced by activated platelets within the thrombus. Viridans streptococci are especially resistant to these plateletderived factors [8].

To replicate within the fibrin-platelet aggregate, bacteria must be able to obtain nutrients from their immediate environment. In the oral cavity, streptococci obtain nutrients from the host diet and from the degradation of salivary glycoproteins [9-12]. To grow and multiply at extra-oral sites, they must similarly obtain nutrients from serum proteins and glycoproteins which must first be degraded by bacterial glycosidic and proteolytic enzymes.

S. oralis strains produce a wide range of glycosidic 
enzymes (neuraminidase, $\beta$ - $\mathrm{N}$-acetylgalactosaminidase, $\beta$-N-acetylglucosaminidase and $\beta$-galactosidase) that are able to mediate the degradation of glycoprotein oligosaccharide side chains $[10,13,14]$ and provide fermentable carbohydrates for growth. The production of glycosidases facilitates the growth of this species in the oral cavity and may also contribute to the association of $S$. oralis with infective endocarditis [5] and septicaemia in neutropenic cancer patients [15-16]. This species also produces a wide range of proteolytic enzyme activities with the ability to degrade bovine serum albumin and transferrin [17, 18 ] and members of the 'oralis-group' of streptococci (S. oralis and $S$. mitis) are the most proteolytic of all the viridans streptococci [17]. The influence of the presence of glycoproteins on the production of these enzyme activities is not clear. Therefore, the effect of a model glycoprotein, porcine gastric mucin (PGM [19]), on the production of selected glycosidic and proteolytic enzyme activities by strains of $S$. oralis was investigated, as the ability to degrade such macromolecules might influence their growth and virulence in vivo.

\section{Materials and methods}

\section{Bacterial strains}

S. oralis strains SS1802 and SS2099 were isolated from blood cultures of patients with infective endocarditis at the Royal London Hospital, strains 92C16 and 92B88 were isolated from blood cultures of neutropenic cancer patients at Withington Hospital, Manchester (kindly provided by Dr Beryl Oppenheim) and strains 341 and 311 were isolated from the normal oral flora of students. All the isolates were identified by testing for the production of a range of glycosidic enzyme activities with 4-methylumbelliferyl-(4-MU-)-linked fluorogenic substrates, and for their reaction in a range of conventional fermentation and hydrolytic tests as described previously [14]. Bacterial strains were maintained at $-70^{\circ} \mathrm{C}$ on beads in cryovials (Pro Lab Diagnostics, Wirral) and routinely cultured on Columbia Agar (Oxoid) supplemented with horse blood 5\% $\mathrm{v} / \mathrm{v}$ (CA). Cultures were incubated in an anaerobic chamber (Don Whitley, Shipley, W. Yorks) with an atmosphere of $\mathrm{H}_{2} 10 \%, \mathrm{CO}_{2} 10 \%$ and $\mathrm{N}_{2} 80 \%$ at $37^{\circ} \mathrm{C}$ for 24 or $48 \mathrm{~h}$.

\section{Preparation of bacterial suspensions}

$S$. oralis strains were cultured on $\mathrm{CA}$ and bacterial colonies were removed into $50 \mathrm{mM} \mathrm{N}$-Tris[hydroxymethyl]methyl-2-aminoethanesulphonic acid buffer, $\mathrm{pH}$ 7.5 (TES buffer; Sigma) to form a uniform suspension. Suspensions were centrifuged at $2700 \mathrm{~g}$ (Labofuge 6000 , Heraeus) for $10 \mathrm{~min}$; the supernates were discarded and the pellets were washed by centrifugation and resuspended in the same buffer to give an absorbance of 0.1 at $620 \mathrm{~nm}$.

\section{Determination of $p H$ optima of protease and glycosidase activities}

The following fluorogenic (7-amido-4-methylcoumarinlinked; AMC-linked) protease substrates (Sigma) were used in all experiments: NE-CBZ-L-lysine-AMC (CBZlys-AMC), glycyl-prolyl-AMC (gly-pro-AMC), L-leucine-AMC (leu-AMC) and N-t-BOC-leucyl-seryl-threonyl-arginyl-AMC (BOC-leu-ser-thr-arg-AMC). These substrates were selected for study because it has been reported previously that they may represent the principal proteolytic activities of $S$. oralis [17]. The following buffers were prepared at a concentration of $0.2 \mathrm{M}$ for use in protease assays: sodium citrate buffer $\mathrm{pH} 3.0,3.5,4.0,4.5,5.0,5.5$ and 6.0 ; potassium phosphate buffer $\mathrm{pH} 6.0,6.5,7.0,7.5$ and 8.0 ; and sodium borate buffer $\mathrm{pH} 8.1,9.0,9.3,9.5,10.1,10.5$ and 10.7 .

Each S. oralis strain was tested for its ability to degrade the following fluorogenic (4-MU-linked) glycosidase substrates: 4-MU- $\alpha$-N-acetyl-neuraminic acid (4-MU-NeuAc), 4-MU-N-acetyl- $\beta$-D-glucosaminide (4-MU- $\beta$-GlcNAc), 4 -MU-N-acetyl- $\beta$-D-galactosaminide (4-MU- $\beta$-GalNAc) and 4-MU- $\beta$-D-galactoside (4-MU- $\beta$-Gal). Buffers used for the glycosidase assays, all at a concentration of $0.2 \mathrm{M}$, were sodium citrate $\mathrm{pH} 3.0,3.5,4.0,4.5,5.0,5.5$ and 6.0 ; sodium phosphate $\mathrm{pH} 6.0,6.5,7.0,7.5$ and 8.0 ; potassium phosphate $\mathrm{pH}$ 6.5, 7.0 and 7.5; and Tris- $\mathrm{HCl} \mathrm{pH} \mathrm{7.5,}$ $8.0,8.5$ and 8.9 .

Assays were set up in triplicate in 96-well flatbottomed microtitration trays (ICN-Flow, High Wycombe, Bucks) and contained $35 \mu \mathrm{l}$ of buffer at the appropriate $\mathrm{pH}, 30 \mu \mathrm{l}$ of distilled water, $25 \mu \mathrm{l}$ of $400 \mu \mathrm{M}$ substrate solution and $10 \mu \mathrm{l}$ of cell suspension. Control assays contained $10 \mu \mathrm{l}$ of TES buffer in place of the cell suspension. The microtitration trays were incubated at $37^{\circ} \mathrm{C}$ aerobically for up to $24 \mathrm{~h}$ and the reactions were stopped by the addition of $100 \mu \mathrm{l}$ of $0.5 \mathrm{M} \mathrm{NaHCO} / \mathrm{Na}_{2} \mathrm{CO}_{3}$ buffer, pH 10.2 (stop buffer). Substrate hydrolysis was determined by measuring the increase in fluorescence at excitation and emission wavelengths of $380 \mathrm{~nm}$ and $460 \mathrm{~nm}$, respectively (LS3B fluorescence spectrometer fitted with a microtitration plate-reading attachment; Perkin-Elmer, Beaconsfield, Hants). The number of moles of substrate hydrolysed was calculated by reference to standard curves prepared wtih 4-methylumbelliferone or 7amido-4-methylcoumarin (for glycosidase and protease assays, respectively) and treated with $100 \mu$ l of stop buffer, as described above.

\section{Determination of Michaelis constant $\left(K_{m}\right)$ of protease and glycosidase activities}

The $\mathrm{K}_{m}$ for the hydrolysis of each of the eight protease and glycosidase substrates was determined at the $\mathrm{pH}$ optimum of the individual enzyme. The substrates were 
used at final concentrations ranging from $0.0055 \mathrm{mM}$ to $5.5 \mathrm{mM}$. Assays were set up in triplicate in microtitration trays and contained: $35 \mu \mathrm{l}$ of $0.2 \mathrm{M}$ buffer, $55 \mu \mathrm{l}$ of substrate at the appropriate concentration and $10 \mu \mathrm{l}$ of cell suspension. Trays were incubated aerobically at $37^{\circ} \mathrm{C}$ for an appropriate period, dependent upon the rate of reaction for each enzyme activity and, after the addition of stop buffer, fluorescence values were determined as described above. Control assays were set up with TES buffer in place of the bacterial suspension for each concentration of substrate.

\section{Induction of protease and glycosidase activities}

The production of glycosidic and proteolytic enzymes by $S$. oralis strains was investigated after growth in a semi-defined medium (CASMM) supplemented with glucose or porcine gastric mucin (PGM). CASMM, containing casein hydrolysate $5 \mathrm{~g} / \mathrm{L}$, was prepared as described previously [20] and dispensed into sterile 7$\mathrm{ml}$ screw-capped containers in $2.5-\mathrm{ml}$ portions; $2.5 \mathrm{ml}$ of $20 \mathrm{mM}$ glucose or PGM $10 \mathrm{mg} / \mathrm{ml}$ or mixtures of these two were added and the media were pre-reduced. Individual bacterial colonies from $\mathrm{CA}$ were removed into pre-reduced Brain Heart Infusion Broth (BHI; Oxoid) and incubated anaerobically to attain late exponential or early stationary phase. CASMM with supplements was inoculated with $200 \mu \mathrm{l}$ of the BHI starter cultures and incubated anaerobically at $37^{\circ} \mathrm{C}$ for up to $24 \mathrm{~h}$. Each culture was set up in triplicate and the mean value of each determination was calculated.

One-ml volumes of each culture were centrifuged at $11600 \mathrm{~g}$ for $5 \mathrm{~min}$ (MSE, Microcentrifuge) and the supernates were decanted. Bacterial pellets were washed by centrifugation in $10 \mathrm{mM}$ potassium phosphate buffer, $\mathrm{pH} 7.5$, and resuspended in the same buffer. The assays for supernate and cell-associated protease and glycosidase activities were performed in duplicate with $20 \mu \mathrm{l}$ of cell suspension or culture supernate, $35 \mu \mathrm{l}$ of the $0.2 \mathrm{M}$ buffer (chosen according to the previously determined $\mathrm{pH}$ optimum for the enzyme), $20 \mu \mathrm{l}$ of distilled water, and $25 \mu \mathrm{l}$ of $1 \mathrm{mM}$ substrate (except for 4-MU-NeuAc which was used at a concentration of $0.1 \mathrm{mM}$ ). Assays were set up in microtitration trays and incubated at $37^{\circ} \mathrm{C}$. Reactions were terminated by the addition of $100 \mu \mathrm{l}$ of stop buffer and the fluorescence was determined as described above. The cell-associated and supernate activity of individual enzymes was calculated as nmoles of substrate hydrolysed/min $/ \mathrm{mg}$ of bacterial protein and the mean values were calculated for each strain.

\section{Determination of phosphoenolpyruvate:sugar phosphotransferase system (PTS) activities}

The influence of PGM on PTS activity was tested with strain SS1802 grown anaerobically in CASMM supplemented with either glucose or PGM (final concentra- tions of $10 \mathrm{mM}$ and $5 \mathrm{mg} / \mathrm{ml}$, respectively) for $18-24 \mathrm{~h}$. Cells were harvested, washed by centrifugation in $50 \mathrm{mM}$ potassium phosphate buffer, $\mathrm{pH} 7.5$, and resuspended in the same buffer to give an optical density of 2.0 at $620 \mathrm{~nm}$ (Shimadzu UV-160A recording spectrophotometer). Cell suspensions were decryptified by mixing $2 \mathrm{ml}$ of bacterial suspension with $20 \mu \mathrm{l}$ of a toluene:acetone (1:4 v:v) mixture and vigorously mixing at room temperature for $90 \mathrm{~s}$ with a vortex mixer. Decryptified cell suspensions were stored on ice.

Assays for the measurement of PTS activity were performed by a previously described method [21] and contained: $250 \mu \mathrm{l}$ of $100 \mathrm{mM}$ potassium phosphate buffer, $\mathrm{pH} 7.0 ; 100 \mu \mathrm{l}$ of $10 \mathrm{mM}$ phosphoenolpyruvate; $50 \mu \mathrm{l}$ of lactate dehydrogenase (LDH) $40 \mathrm{U} / \mathrm{ml} ; 100 \mu \mathrm{l}$ of $10 \mathrm{mM} \mathrm{MgCl}$; $100 \mu \mathrm{l}$ of $100 \mathrm{mM} \mathrm{NaF} ; 200 \mu \mathrm{l}$ of decryptified cell suspension; $100 \mu \mathrm{l}$ of $1 \mathrm{mM}$ NADH and $100 \mu \mathrm{l}$ of $100 \mathrm{mM}$ carbohydrate solution. The following carbohydrates were used: glucose, $\mathrm{N}$-acetylglucosamine, mannose, galactose and mannitol as a negative control. All components, except for the prewarmed carbohydrate, were added to a $1.0-\mathrm{ml} \mathrm{UV}$ transparent disposable cuvette (Elkay) and pre-warmed at $37^{\circ} \mathrm{C}$ for $10 \mathrm{~min}$. Reactions were initiated by the addition of the carbohydrate solution and the change in absorbance at $340 \mathrm{~nm}$ was monitored. Control assays contained all components, except that distilled water replaced the carbohydrate solution. The rate of NADH oxidation was calculated by comparison with a standard curve of NADH. PTS activity was expressed as $\mu \mathrm{mol} \mathrm{NADH}$ oxidised $/ \mathrm{h} / \mathrm{mg}$ of protein.

\section{Determination of neuraminate pyruvate-lyase (NPL) activity}

NPL, the first enzyme in the pathway of intracellular $\mathrm{N}$-acetylneuraminic acid catabolism, catalyses the conversion of this compound to pyruvate and $\mathrm{N}$ acetylmannosamine. S. oralis strain $\mathrm{SS} 1802$ was grown on CASMM supplemented with $10 \mathrm{mM}$ glucose or PGM $5 \mathrm{mg} / \mathrm{ml}$ and cells were pelleted by centrifugation. Cell-free extracts were prepared by disrupting cells with Ballotini beads (size 12, Jencons) in a Mickle disintegrator (Mickle Engineering Co., Gomshall, Surrey) for $10 \mathrm{~min}$ at $4^{\circ} \mathrm{C}$. Cell debris was removed by centrifugation (11600 $\mathrm{g}$, MSE Microfuge, $10 \mathrm{~min}$ ) and the cell-free supernate was assayed for NPL activity.

Preliminary experiments to measure NPL activity were performed with the method described by Homer et al. [20] and demonstrated that the rate of endogenous $\mathrm{NADH}$ oxidation, in the absence of $\mathrm{N}$-acetyl-neuraminic acid, was high and significantly interfered with the measurement of NPL activity in $S$. oralis. Therefore, a modification of an earlier method was used [22] in which the reaction was terminated by heat inactivation of bacterial enzymes and released 
pyruvate was measured by coupling with $\mathrm{LDH}$ in the presence of NADH. Assays for NPL activity were set up in microcentrifuge tubes and contained: $100 \mu \mathrm{l}$ of $0.2 \mathrm{M}$ sodium phosphate buffer, $\mathrm{pH} 7.5 ; 40 \mu 1$ of $0.1 \mathrm{M}$ $\mathrm{N}$-acetylneuraminic acid; $100 \mu \mathrm{l}$ of cell-free extract; and $160 \mu \mathrm{l}$ of distilled water. Assays were incubated at $37^{\circ} \mathrm{C}$ for up to $1 \mathrm{~h}$ and the reaction was stopped by heating at $100^{\circ} \mathrm{C}$ for $2 \mathrm{~min}$. After cooling to room temperature, the assay mixtures were transferred to UV-transparent cuvettes to which $200 \mu \mathrm{l}$ of $50 \mathrm{mM}$ sodium phosphate buffer, $\mathrm{pH} 7.5,200 \mu \mathrm{l}$ of $1 \mathrm{mM}$ NADH solution and $200 \mu \mathrm{l}$ of distilled water were added. After equilibration at $37^{\circ} \mathrm{C}$, the absorbance at $340 \mathrm{~nm}$ was recorded and $10 \mu \mathrm{l}$ of $\mathrm{LDH} 40 \mathrm{U} / \mathrm{ml}$ solution was added. The absorbance at $340 \mathrm{~mm}$ was monitored until a minimum value was reached. Control assays contained no sialic acid but $40 \mu \mathrm{l}$ of distilled water was used to maintain the volume of the assay. The amount of pyruvate formed in NPL assays was calculated by comparison with standard concentrations of pyruvate treated with $\mathrm{LDH}$ as described above. Specific activity was expressed as $\mu \mathrm{mol} / \mathrm{h} / \mathrm{mg}$ of protein.

\section{Protein determinations}

Protein concentrations of bacterial cell suspensions or crude cell-free extracts were determined with the Coomassie Blue dye-binding assay (Sigma Kit No. $610-A)$ with bovine serum albumin as the standard.

\section{Results}

\section{pH optima of protease activities}

The influence of assay $\mathrm{pH}$ on the rate of hydrolysis of BOC-leu-ser-thr-arg-AMC, CBZ-lys-AMS, gly-proAMC and leu-AMC by $S$. oralis strain SS1802 is shown in Fig. 1. All proteases exhibited maximum activity at $\mathrm{pH} 8.0$, with the exception of the enzyme acting on CBZ-lys-AMC which had a $\mathrm{pH}$ optimum of c. 6.5. These data are similar to $\mathrm{pH}$ profiles obtained for protease activities of the other $S$. oralis strains (data not shown). The $\mathrm{pH}$ optima for the proteases of all the $S$. oralis strains are shown in Table 1 . The $\mathrm{pH}$ optima for each of these activities were generally between $\mathrm{pH}$ 6.0 and 8.0 except for gly-pro-AMC activity which was between $\mathrm{pH} 8.0$ and 9.3. The $\mathrm{pH}$ range over which these enzymes exhibited $\geqslant 50 \%$ of the maximum activity was $6.0-9.5$ for leu-AMC, $6.2->10$ for glypro-AMC, 5.5-9.3 for CBZ-lys-AMC and 5.5-9.2 for BOC-leu-ser-thr-arg-AMC.

\section{pH optima of glycosidase activities}

The effect of $\mathrm{pH}$ on the activity of the glycosidases produced by $S$. oralis strain SS1802, and typical of all the other strains, is shown in Fig. 2. The pH optima for $\mathrm{N}$-acetylglucosaminidase and $\mathrm{N}$-acetylgalactosimini- dase were 4.5 , whereas those of sialidase and $\beta$ galactosidase were 6.0 , although all four glycosidases exhibited activity over a wide $\mathrm{pH}$ range. The $\mathrm{pH}$ optima for the glycosidases of each of the six strains are shown in Table 2. N-acetylglucosaminidase and $\mathrm{N}$ acetylgalactosaminidase exhibited maximum activity at $\mathrm{pH} 4.5$ or 5.0 ; the sialidase and $\beta$-galactosidase enzymes were most active at $\mathrm{pH} 6.0$ or 6.5 . The $\mathrm{pH}$ range over which all glycosidases exhibited at least $50 \%$ of their maximum activity was wide, spanning 2$3 \mathrm{pH}$ units.

\section{Michaelis constants $\left(K_{m}\right)$ of proteases and glycosidases}

The $\mathrm{K}_{m}$ values for proteases and glycosidases produced by each of the six $S$. oralis strains were determined at the $\mathrm{pH}$ optimum for each enzyme and the mean $\mathrm{K}_{m}$ for the six strains for each substrate was calculated. Of the proteolytic activities, the enzyme degrading CBZ-lysAMC usually exhibited the lowest $\mathrm{K}_{m}$ and the enzyme acting on gly-pro-AMC showed the highest (Table 3). The mean $\mathrm{K}_{m}$ values were $24 \mu \mathrm{M}$ for CBZ-lys-AMC, $55 \mu \mathrm{M}$ for leu-AMC, $101 \mu \mathrm{M}$ for BOC-leu-ser-thr-arg$\mathrm{AMC}$ and $793 \mu \mathrm{M}$ for gly-pro-AMC.

The mean $\mathrm{K}_{m}$ values for the four glycosidase activities were calculated and were $28 \mu \mathrm{M}$ for sialidase, $244 \mu \mathrm{M}$ for $\mathrm{N}$-acetylglucosaminidase, $42 \mu \mathrm{M}$ for $\mathrm{N}$-acetylgalactosaminidase and $460 \mu \mathrm{M}$ for $\beta$ galactosidase (Table 4). For all strains, the $\mathrm{K}_{m}$ for the sialidase substrate was usually the lowest and that for 4-MU- $\beta$-gal was the greatest.

\section{Influence of PGM on protease activities}

The mean cell-associated proteolytic activities of the $S$. oralis strains grown in CASMM supplemented with $10 \mathrm{~mm}$ glucose are shown in Table 5. The highest specific activities were obtained when gly-pro-AMC was the substrate and the lowest with BOC-leu-ser-thrarg-AMC, irrespective of the strain. Cells from cultures in CASMM with PGM exhibited significantly less protease activity than those which were grown in the presence of glucose (Table 5). For the cultures grown with glucose the supernate specific activities were much less than the cell-associated levels, being $8.3 \%, 4.7 \%, 9.1 \%$ and $34 \%$ for leu-AMC, gly-proAMC, CBZ-lys-AMC and BOC-leu-ser-thr-arg-AMC, respectively. There was no detectable protease activity in the supernate from the cultures supplemented with PGM.

\section{Influence of PGM on glycosidase activities}

Table 6 shows the mean specific activities of glycosidases of the six strains of $S$. oralis grown on CASMM supplemented with $10 \mathrm{mM}$ glucose, PGM or a combination of glucose and PGM. The specific activity of each of the cell-associated glycosidases was greatest 

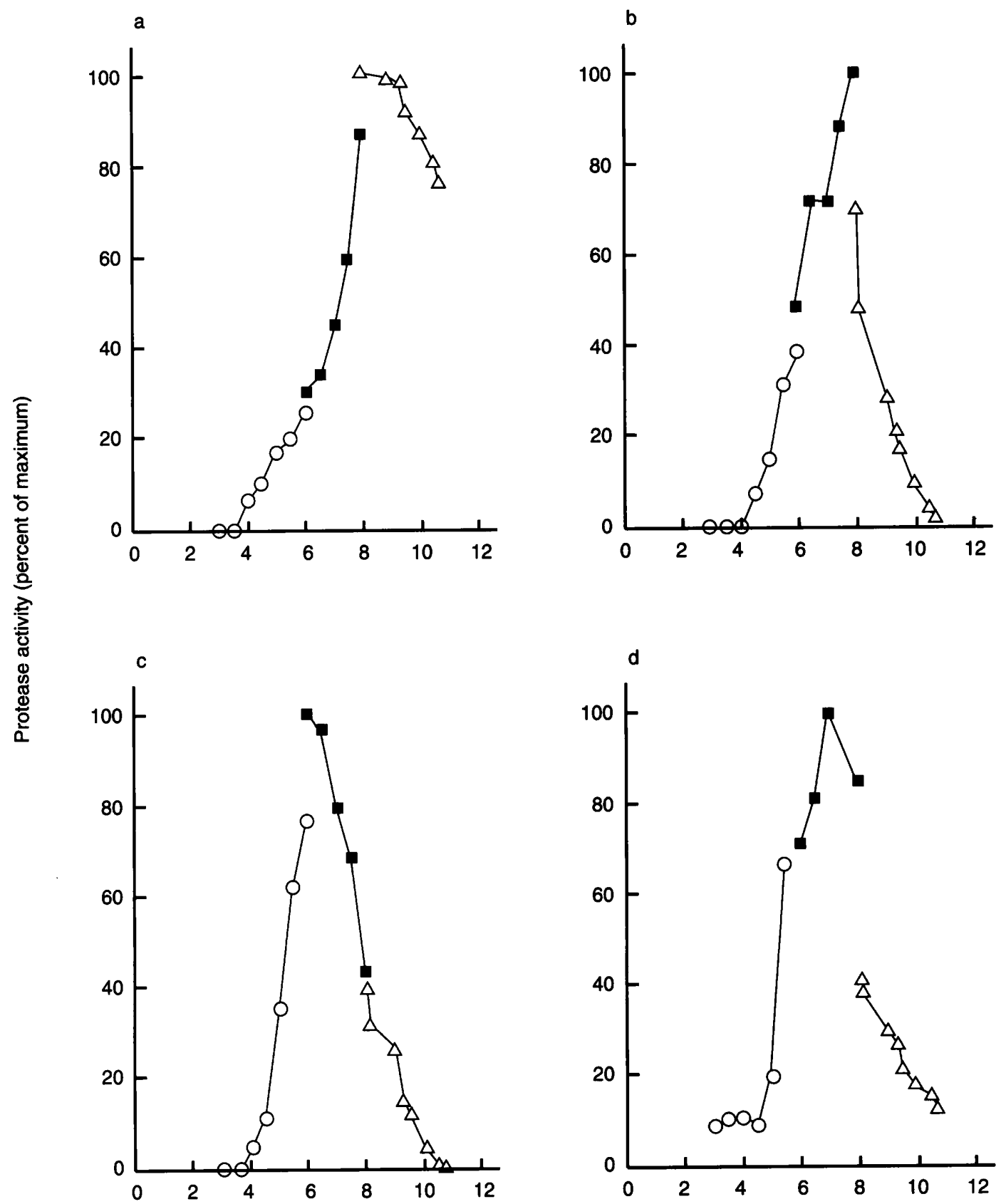

$\mathrm{pH}$ value

Fig 1. $\mathrm{pH}$ optima of $S$. oralis strain SS1802 proteases. Activity is given as a percentage of the maximum for each protease substrate: a, Gly-pro-AMC; b, Leu-AMC; c, CBZ-lys-AMC; d, BOC-leu-ser-thr-arg-AMC. Buffers: O, sodium citrate; $\mathbf{\square}$, potassium phosphate; $\triangle$, sodium borate.

Table 1. $\mathrm{pH}$ optima and ranges of $S$. oralis protease activities

\begin{tabular}{|c|c|c|c|c|c|c|c|c|}
\hline \multirow{3}{*}{ Strain no. } & \multicolumn{8}{|c|}{$\mathrm{pH}$ values with } \\
\hline & \multicolumn{2}{|c|}{ leu-AMC } & \multicolumn{2}{|c|}{ gly-pro-AMC } & \multicolumn{2}{|c|}{ CBZ-lys-AMC } & \multicolumn{2}{|c|}{ BOC-leu-ser-thr-arg-AMC } \\
\hline & optimum & $50 \%$ range $^{*}$ & optimum & $50 \%$ range & optimum & $50 \%$ range & optimum & $50 \%$ range \\
\hline SS1802 & 8.0 & $6.0-8.5$ & 8.1 & $7.2->10$ & 6.0 & $5.5-7.5$ & 8.0 & $5.5-9.0$ \\
\hline SS2099 & 8.0 & $6.0-9.5$ & 9.3 & $7.5->10$ & 6.0 & $5.5-8.0$ & 7.0 & $6.0-9.2$ \\
\hline $92 \mathrm{~B} 88$ & 8.0 & $6.0-8.5$ & 8.1 & $6.2->10$ & 6.0 & $6.0-9.3$ & 7.5 & $5.8-9.0$ \\
\hline $92 \mathrm{C} 16$ & 8.0 & $6.0-8.5$ & 8.0 & $6.5->10$ & 6.0 & $6.0-8.0$ & 8.0 & $5.8-9.0$ \\
\hline 311 & 8.0 & $6.0-9.0$ & 8.0 & $6.5->10$ & 6.0 & $6.0-8.5$ & 7.0 & $6.0-9.0$ \\
\hline 341 & 8.0 & $6.5-8.5$ & 8.1 & $7.3->10$ & 6.0 & $6.0-7.5$ & 7.5 & $6.0-9.0$ \\
\hline
\end{tabular}

${ }^{*}$ Range over which enzyme activity was $\geqslant 50 \%$ of the activity at the pH optimum. 


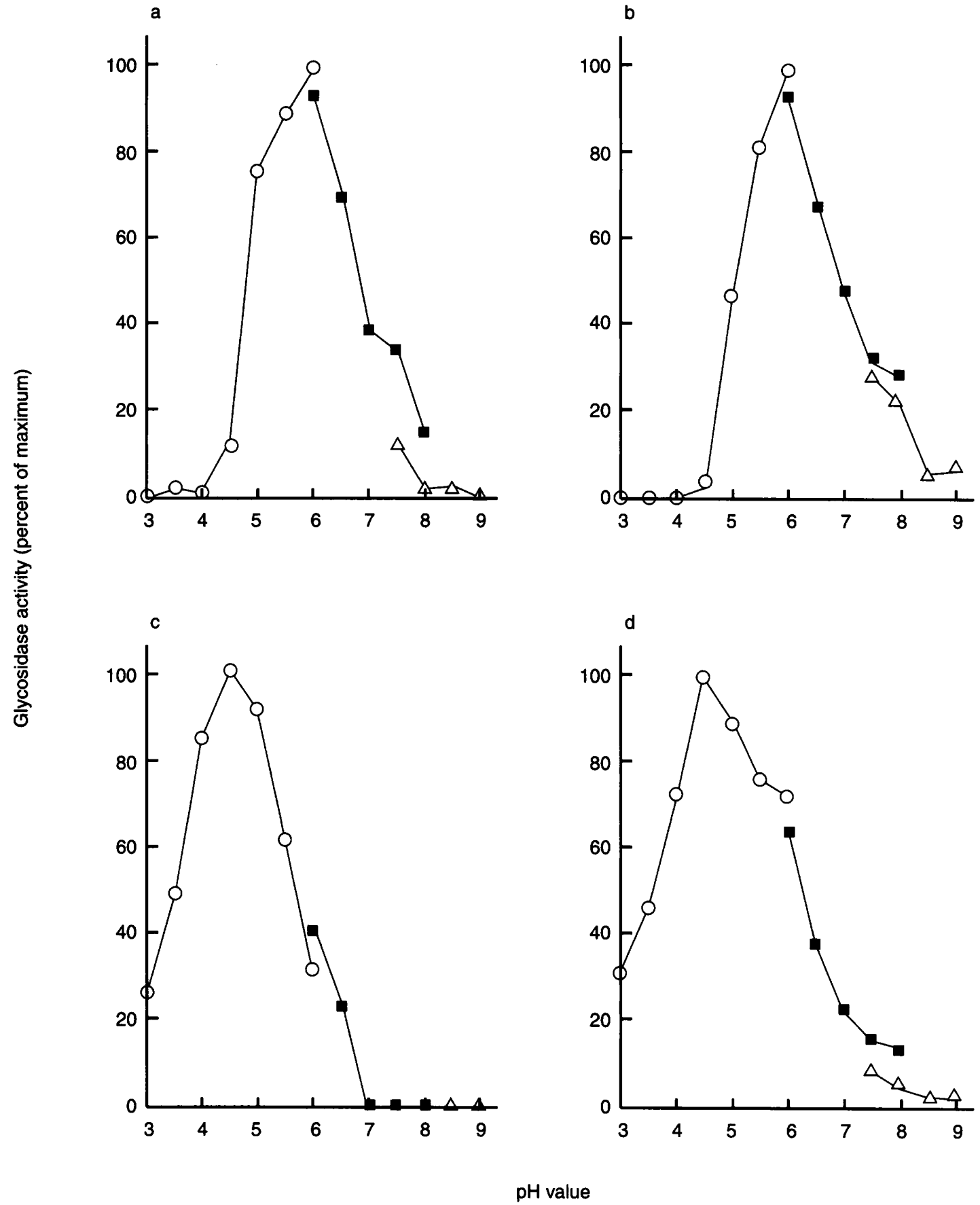

Fig 2. pH optima of $S$. oralis strain SS1802 glycosidases. Activity is given as a percentage of the maximum for each protease substrate. a, $4-\mathrm{MU}-\beta$-Gal; b, 4-MU-NeuAc; c, $4-\mathrm{MU}-\beta$-GalNAc; d, 4-MU- $\beta$-GlcNAc. Buffers: $O$, sodium citrate; $\mathbf{\square}$, potassium phosphate; $\triangle$, Tris- $\mathrm{HCl}$.

Table 2. $\mathrm{pH}$ optima and ranges of $S$. oralis glycosidase activities

\begin{tabular}{|c|c|c|c|c|c|c|c|c|}
\hline \multirow{3}{*}{ Strain no. } & \multicolumn{8}{|c|}{$\mathrm{pH}$ values with } \\
\hline & \multicolumn{2}{|c|}{ 4-MU-NeuAc } & \multicolumn{2}{|c|}{ 4-MU- $\beta$-GlcNAc } & \multicolumn{2}{|c|}{ 4-MU- $\beta$-GalNAc } & \multicolumn{2}{|c|}{ 4-MU- $\beta$-Gal } \\
\hline & optimum & $50 \%$ range* & optimum & $50 \%$ range & optimum & $50 \%$ range & optimum & $50 \%$ range \\
\hline SS1802 & 6.0 & $5.0-7.0$ & 4.5 & $3.5-6.5$ & 4.5 & $3.5-6.0$ & 6.0 & $4.5-7.0$ \\
\hline SS2099 & 6.0 & $5.0-7.5$ & 5.0 & $3.5-6.5$ & 4.5 & $3.5-6.5$ & 6.5 & $4.5-7.5$ \\
\hline $92 \mathrm{~B} 88$ & 6.0 & $5.5-7.5$ & 4.5 & $3.5-6.5$ & 4.5 & $3.5-5.5$ & 6.0 & $5.0-7.0$ \\
\hline $92 \mathrm{C} 16$ & 6.0 & $5.5-7.5$ & 5.0 & $4.0-6.0$ & 4.5 & $4.0-6.0$ & 6.0 & $5.5-7.0$ \\
\hline 311 & 6.0 & $5.5-7.5$ & 4.5 & $3.5-6.5$ & 4.5 & $3.5-5.5$ & 6.0 & $5.5-7.0$ \\
\hline 341 & 6.0 & $5.5-7.5$ & 5.0 & $3.5-6.5$ & 4.5 & $3.5-6.0$ & 6.0 & $4.5-7.5$ \\
\hline
\end{tabular}

${ }^{*}$ Range over which enzyme activity was $\geqslant 50 \%$ of the activity at the $\mathrm{pH}$ optimum. 
Table 3. $\mathrm{K}_{m}$ values of protease activities of $S$. oralis strains determined at the $\mathrm{pH}$ optima

\begin{tabular}{|c|c|c|c|c|}
\hline \multirow[b]{2}{*}{$\begin{array}{l}\text { Strain } \\
\text { no. }\end{array}$} & \multicolumn{4}{|c|}{$\mathrm{K}_{m}$ value $(\mu \mathrm{M})$ with } \\
\hline & leu-AMC & $\begin{array}{c}\text { gly-pro- } \\
\text { AMC }\end{array}$ & $\begin{array}{c}\text { CBZ-lys- } \\
\text { AMC }\end{array}$ & $\begin{array}{l}\text { BOC-leu-ser- } \\
\text { thr-arg-AMC }\end{array}$ \\
\hline SS1802 & 37 & 442 & 12 & 106 \\
\hline SS2099 & 11 & 2097 & 26 & 38 \\
\hline 92B88 & 38 & 253 & 18 & 112 \\
\hline $92 \mathrm{C} 16$ & 56 & 1412 & 11 & 100 \\
\hline 311 & 138 & 453 & 60 & 130 \\
\hline 341 & 50 & 117 & 20 & 120 \\
\hline
\end{tabular}

Fluorogenic substrates were included in the assays at concentrations up to $5.5 \mathrm{mM}$.

in the medium supplemented with PGM and significantly reduced when bacteria were grown in CASMM supplemented with glucose alone. The combination of PGM and glucose produced intermediate levels of each glycosidase. Supernatant glycosidase activities were greatest in the cultures with PGM and lowest in the medium supplemented with glucose alone.

\section{Induction of PTS and NPL activities}

$S$. oralis strain SS1802 was studied for its ability to transport carbohydrates via PTS systems after growth in CASMM supplemented with $10 \mathrm{mM}$ glucose or PGM $5 \mathrm{mg} / \mathrm{ml}$. Cultures grown with glucose exhibited high levels of glucose, $\mathrm{N}$-acetylglucosamine and mannose transport; neither galactose nor mannitol was transported: When grown in the presence of PGM, glucose, $\mathrm{N}$-acetylglucosamine and mannose were transported at higher rates and significant transport of galactose was also observed (Table 7).

Transport of sialic acid, which does not occur via PTS, was not investigated in this study. Instead, the influence of PGM on the levels of intracellular NPL, the first enzyme in the catabolism of sialic acid was investigated. Extracts of $S$. oralis strain SS1802 grown in the presence of glucose exhibited NPL activity of $1.1 \mu \mathrm{mol} / \mathrm{h} / \mathrm{mg}$; extracts from cells derived from PGMcontaining cultures had NPL activity of $72.4 \mu \mathrm{mol} / \mathrm{h} /$ mg.
Table 5. Effect of glucose and PGM, alone and in combination, on the production of protease activities by S. oralis

\begin{tabular}{lccc}
\hline & \multicolumn{3}{c}{$\begin{array}{c}\text { Mean enzyme activity* } \\
\text { grown with }\end{array}$} \\
\cline { 2 - 4 } Proteolytic activity & \multicolumn{3}{c}{ cells } \\
& glucose & PGM & $\begin{array}{c}\text { glucose }+ \\
\text { PGM }\end{array}$ \\
\hline $\begin{array}{l}\text { leu-AMC } \\
\text { cell-associated }\end{array}$ & 54.8 & $20.5^{\dagger}$ & 64.4 \\
$\begin{array}{l}\text { supernate } \\
\text { gly-pro-AMC } \\
\text { cell-associated }\end{array}$ & $4.7^{\ddagger}$ & $<0.1$ & $<0.1$ \\
$\begin{array}{l}\text { supernate } \\
\text { CBZ-lys-AMC } \\
\text { cell-associated }\end{array}$ & 217.9 & $49.0^{\dagger}$ & 238.4 \\
$\quad$ supernate & $10.2^{\ddagger}$ & $<0.01$ & $<0.01$ \\
BOC-leu-ser-thr-arg-AMC & 22.0 & $5.6^{\dagger}$ & 26.0 \\
$\begin{array}{l}\text { cell-associated } \\
\text { supernate }\end{array}$ & $0.7^{\ddagger}$ & $<0.01$ & $<0.01$ \\
\hline
\end{tabular}

${ }^{*}$ Duplicate determinations of enzyme activities were made on duplicate cultures of each strain; the values given are the means of these determinations and the activities are expressed as nmoles $/ \mathrm{min} /$ $\mathrm{mg}$ of protein except for BOC-leu-ser-thr-arg-AMC which are expressed as nmoles $/ \mathrm{h} / \mathrm{mg}$ of protein.

tValue significantly less than other values in row $(p<0.05)$.

tValue significantly greater than other values in row $(p<0.05)$.

Table 6. Effect of glucose and PGM, alone and in combination, on the production of glycosidases by $S$. oralis strains

\begin{tabular}{lccc}
\hline & \multicolumn{3}{c}{$\begin{array}{c}\text { Mean enzyme activity* in cells } \\
\text { grown with }\end{array}$} \\
\cline { 2 - 4 } Glycosidic activity & glucose & PGM & $\begin{array}{c}\text { glucose }+ \\
\text { PGM }\end{array}$ \\
\hline 4-MU-NeuAc & & & \\
cell-associated & 19.8 & $73.2^{\dagger}$ & 49.8 \\
supernate & 4.6 & $23.7^{\dagger}$ & 11.1 \\
4-MU- $\beta$-GlcNAc & 199.0 & $731.6^{\dagger}$ & 500.1 \\
cell-associated & $30.2^{\dagger}$ & 328.5 & 275.3 \\
supernate & & & \\
4-MU- $\beta$-GalNAc & 79.2 & $207.8^{\dagger}$ & 176.8 \\
cell-associated & 2.1 & $27.4^{\dagger}$ & 7.0 \\
supernate & & & \\
4-MU- $\beta$-D-Gal & & & \\
cell-associated & 8.6 & $31.8^{\dagger}$ & $114.5^{\ddagger}$ \\
supernate & 17.0 \\
\hline
\end{tabular}

${ }^{*}$ Duplicate determinations of enzyme activities were made on duplicate cultures of each strain; the values given are the means of these determinations and the activities are expressed as nmoles $/ \mathrm{min} /$ $\mathrm{mg}$ of protein.

tValue significantly different from all other values in row $(p<0.05)$.

Table 4. $\mathrm{K}_{m}$ values of glycosidase activities of $S$. oralis strains determined at the $\mathrm{pH}$ optima

\begin{tabular}{lcccc}
\hline & \multicolumn{5}{c}{$\mathrm{K}_{m}$ value $(\mu \mathrm{M})$ with } \\
\cline { 2 - 5 } Strain no. & 4-MU-NeuAc & 4-MU- $\beta$-GalNAc & 4-MU- $\beta$-GlcNAc & 4-MU- $\beta$-Gal \\
\hline SS1802 & 8 & 195 & 49 & 511 \\
SS2099 & 12 & 180 & 40 & 393 \\
92B88 & 64 & 237 & 38 & 511 \\
92C16 & 27 & 418 & 50 & 450 \\
311 & 41 & 171 & 47 & 410 \\
341 & 16 & 265 & 29 & 488 \\
\hline
\end{tabular}

Fluorogenic substrates were included in the assays at concentrations up to $5.5 \mathrm{mM}$. 
Table 7. PTS activities of glucose- and PGM-grown cells of $S$. oralis strain SS1802

\begin{tabular}{lcc}
\hline & \multicolumn{2}{c}{ PTS activity* of cells grown with } \\
\cline { 2 - 3 } Transport assay with & Glucose & PGM \\
\hline Glucose & 1.69 & 6.22 \\
N-Acetylglucosamine & 1.93 & 3.22 \\
Mannose & 1.65 & 4.62 \\
Galactose & $<0.01$ & 0.78 \\
Mannitol & $<0.01$ & $<0.05$ \\
\hline
\end{tabular}

${ }^{*} \mu$ moles NADH oxidised/h/mg of protein.

\section{Discussion}

Some properties of the glycosidic and proteolytic enzymes produced by $S$. oralis that may play a role in the degradation of glycoproteins were investigated. Overall the $\mathrm{pH}$ optima and $\mathrm{K}_{m}$ values for the hydrolysis of each substrate by the strains were similar, irrespective of the origin of the strains. These marked similarities were not unexpected because the source of infection in cases of endocarditis and septicaemia is almost certainly via the oral cavity [23], where $S$. oralis forms a significant proportion of the normal oral flora [1].

The $\mathrm{pH}$ optima for the glycosidases were all acidic, ranging between $\mathrm{pH} 4.5$ and 6.0 , but at least $50 \%$ of maximum activity was exhibited over a considerably wider range. These values were very similar to those reported previously for another oral Streptococcus sp. associated with extra-oral diseases, $S$. intermedius [20]. For the proteases, the $\mathrm{pH}$ optima tended to be more alkaline, within the $\mathrm{pH}$ range $6.0-8.0$, but again the enzymes were active over a broad range. This indicates that these activities may function effectively under different physiological conditions to degrade host glycoproteins yielding both saccharides and peptides from glycoproteins for bacterial growth. The $\mathrm{K}_{m}$ values for the hydrolysis of the different substrates varied considerably. It is of interest that of the $S$. oralis glycosidases, the $\mathrm{K}_{m}$ for sialidase was the lowest, indicating the greatest affinity for its substrate. Sialidase has been implicated as a virulence determinant for several bacterial species [24-26] as the removal of the terminal sialic acid residues on the glycoprotein oligosaccharide side chains is a primary event in glycoprotein deglycosylation and may result in cellular and structural damage [27].

In these studies, PGM was used as a model glycoprotein because of the marked structural resemblance between its oligosaccharide sidechains and the O-linked sidechains of human glycoproteins [19]. PGM also has been used in other in-vitro studies to support the growth of mixed cultures of dental plaque bacteria with production of glycosidase and proteolytic activities similar to those demonstrable in vivo [2830]. Data from the present study indicate that incorporation of PGM into the minimal medium used for growth of $S$. oralis strains had a marked effect on the production of glycosidic and proteolytic enzymes. Proteolytic activities were greatest in medium containing glucose and lowest in the medium supplemented with PGM alone, whereas glycosidase activities were greatest in medium containing PGM and lowest in the medium supplemented with glucose. All media contained casein hydrodysate $0.5 \% \mathrm{w} / \mathrm{v}[20]$ as a component of the CASMM. These data suggest that in the glucose-containing medium there was an excess of carbon (as glucose), the utilisation of which depended upon an adequate supply of nitrogen. The increased proteolytic activities and the repression of glycosidase activities may be a direct response to the high concentration of glucose in the medium [31]. The nitrogen requirement for growth may have been satisfied by the hydrolysis of, and utilisation of peptides derived from, the casein hydrolysate in the medium. This hydrolytic process, occurring under conditions of carbon excess, would require the increased production of proteolytic enzymes.

When $S$. oralis strains were cultured in minimal medium supplemented with PGM, glycosidic activities, with the potential to degrade oligosaccharide sidechains of PGM, were induced. Furthermore, PGM influenced the ability of the $S$. oralis cells to transport carbohydrates. Increased levels of PTS activity were observed for $\mathrm{N}$-acetylglucosamine, glucose and mannose with low levels of PTS activity for galactose. Similar changes in these transport systems were apparent in $S$. intermedius grown under the same culture conditions with PGM as the major source of carbohydrate [20]. The transport of $\mathrm{N}$-acetylneuraminic acid, which occurs via a specific permease and not via a PTS system [32, 33], was not studied directly here but, as in $S$. intermedius [20], there were increased levels of neuraminate pyruvate-lyase activity, indicating intracellular catabolism of $\mathrm{N}$-acetylneuraminic acid in cells grown in media supplemented with PGM. These data suggest that, under these cultural conditions, $S$. oralis exhibits the ability to catabolise, simultaneously, monosaccharides derived from oligosaccharide side chains of PGM and, probably, side chains of other glycoproteins with similar structures. The reduced protease activity and elevated glycosidase activity suggest that in the PGM cultures the cells are adequately provided with nitrogenous substrates by the actions of the proteases and that the growth of the bacteria depended upon the rate at which carbohydrate moieties were liberated from the oligosaccharide sidechains of the PGM.

These studies were preliminary investigations into the regulation of the expression of metabolic activities which may be required for the growth and persistence of bacteria in vivo. The simple attachment of bacteria to host tissue or their presence in the circulation are insufficient to initiate disease [34]. The bacteria must, 
amongst other things, be able to grow and this is mediated by the binding of glycoproteins, their degradation and the subsequent utilisation of the carbohydrate and peptide moieties derived from them.

This study was funded in part by the British Heart Foundation Grant No. PG/93049.

\section{References}

1. Frandsen EVG, Pedrazzoli V, Kilian M. Ecology of viridans streptococci in the oral cavity and pharynx. Oral Microbiol Immunol 1991; 6: 129-133.

2. Manford M, Matharu J, Farrington K. Infective endocarditis in a district general hospital. $J R$ Soc Med 1992; 85: 262-266.

3. Bayliss R, Clarke C, Oakley C, Somerville W, Whitfield AGW. The teeth and infective endocarditis. Br Heart $J$ 1983; 50: 506-512.

4. Bouvet A, Durand A, Devine C, Etienne J, Leport $\mathrm{C}$ and the Groups d'Enquête sur I'Endocardite en France en 1990-1991. In: Totolian A (ed) Pathogenic streptococci: present and future. St Petersburg, Lancer Publication 1994: 72-73.

5. Douglas CWI. Pathogenic mechanisms in infective endocarditis. Rev Med Microbiol 1993; 4: 130-137.

6. Bayliss R, Clarke C, Oakley CM, Somerville W, Whitfield $\mathrm{AGW}$, Young SEJ. Incidence, mortality and prevention of infective endocarditis. $J R$ Coll Phys Lond 1986; 20: 15-20.

7. Gould K, Ramirez-Ronda CH, Holmes RK, Sanford JP. Adherence of bacteria to heart valves in vitro. $J$ Clin Invest 1975; 56: 1364-1370.

8. Wu T, Yeaman MR, Bayer AS. In vitro resistance to platelet microbicidal protein correlates with endocarditis source among bacteremic staphylococcal and streptococcal isolates. Antimicrob Agents Chemother 1994; 38: 729-732.

9. Beckers HJA, van der Hoeven JS. Growth rates of Actinomyces viscosus and Streptococcus mutans during early colonization of tooth surfaces in gnotobiotic rats. Infect Immun 1982; 35: 583587.

10. Beighton D, Hayday $H$. The influence of diet on the growth of streptococcal bacteria on the molar teeth of monkeys (Macaca fascicularis). Arch Oral Biol 1986; 31: 449-454.

11. Beighton D, Smith K, Hayday H. The growth of bacteria and production of exoglycosidic enzymes in the dental plaque of macaque monkeys. Arch Oral Biol 1986; 31: 829-835.

12. De Jong MH, Van der Hoeven JS. The growth of oral bacteria on saliva. $J$ Dent Res 1987: 66: 498-505.

13. Kilian M, Mikkelsen L, Henrichsen J. Taxonomic study of viridans streptococci: description of Streptococcus gordonii sp. nov. and emended descriptions of Streptococcus sanguis (White and Niven 1946), Streptococcus oralis (Bridge and Sneath 1982), and Streptococcus mitis (Andrewes and Horder 1906). Int J Syst Bacteriol 1989; 39: 471-484.

14. Beighton D, Hardie JM, Whiley RA. A scheme for the identification of viridans streptococci. J Med Microbiol 1991; 35: $367-372$

15. Beighton D, Carr AD, Oppenheim BA. Identification of viridans streptococci associated with bacteraemia in neutropenic cancer patients. $J$ Med Microbiol 1994; 40: 202-204.
16. Bochud P-Y, Eggiman P, Calandra T, Van Melle G, Saghafi L, Francioli $P$. Bacteremia due to viridans streptococcus in neutropenic patients with cancer: clinical spectrum and risk factors. Clin Infect Dis 1994; 18: 25-31.

17. Homer KA, Whiley RA, Beighton D. Proteolytic activity of oral streptococci. FEMS Microbiol Lett 1990; 67: 257-260.

18. Homer KA, Beighton D. Synergistic degradation of transferrin by mutans streptococci in association with other dental plaque bacteria. Microb Ecol Hlth Dis 1992; 5: 111-116.

19. Herp A, Wu AM, Moschera J. Current concepts of the structure and nature of mammalian salivary mucous glycoproteins. Mol Cell Biochem 1979; 23: 27-44.

20. Homer KA, Whiley RA, Beighton D. Production of specific glycosidase activities by Streptococcus intermedius strain UNS35 grown in the presence of mucin. $J$ Med Microbiol 1994; 41: 184-190.

21. Homer KA, Patel R, Beighton D. Effects of N-acetylglucosamine on carbohydrate fermentation by Streptococcus mutans NCTC 10449 and Streptococcus sobrinus SL-1. Infect Immun 1993; 61: 295-302.

22. Comb CD, Roseman S. N-Acetylneuraminic acid aldolase. Methods Enzymol 1991; 5: 391-394.

23. Fiehn N-E, Gutschik E, Larsen T, Bangsborg JM. Identity of streptococcal blood isolates and oral isolates from two patients with infective endocarditis. $J$ Clin Microbiol 1995; 33: 1399 1401 .

24. Russo TA, Thompson JS, Godoy VG, Malamy MH. Cloning and expression of the Bacteroides fragilis TAL 2480 neuraminidase gene, nanH, in Escherichia coli. $J$ Bacteriol 1990; 172: 2594-2600.

25. Vimr ER, Lawrisuk L, Galen J, Kaper JB. Cloning and expression of Vibrio cholerae neuraminidase gene nanH in Escherichia coli. J Bacteriol 1988; 170: 1495-1504.

26. Paton JC, Andrew PW, Boulnois GJ, Mitchell TJ. Molecular analysis of the pathogenicity of Streptococcus pneumoniae the role of pneumococcal proteins. Annu Rev Microbiol 1993; 47: $89-115$.

27. Schauer R. Sialic acids and their role as biological masks. Trends Biochem Sci 1985; 10: 357-360.

28. Glenister DA, Salamon K, Smith K, Beighton D, Keevil CW. Enhanced growth of complex communities of dental plaque bacteria in mucin-limited continuous culture. Microb Ecol Hlth Dis 1988; 1: 27-44.

29. Bradshaw DJ, McKee AS, Marsh PD. Effects of carbohydrate pulses and $\mathrm{pH}$ on population shifts within oral microbial communities in vitro. J Dent Res 1989; 68: 1298-1302.

30. Bradshaw DJ, Homer KA, Marsh PD, Beighton D. Metabolic co-operation in oral communities during growth on mucin. Microbiology 1994; 140: 3407-3412.

31. Paigen K, Williams B. Catabolite repression and other control mechanisms in carbohydrate utilization. Adv Microb Physiol 1970; 4: 251-324.

32. Rodríguez-Aparicio LB, Reglero A, Luengo JM. Uptake of Nacetylneuraminic acid by Escherichia coli K-235. Biochem $J$ 1987; 246: 287-294.

33. Aisaka K, Igarashi K, Yamaguchi K, Uwajima T. Purification, crystallization and characterization of $\mathrm{N}$-acetylneuraminate lyase from Escherichia coli. Biochem $J$ 1991; 276: 541-546.

34. Reid G, Bruce AW, McGroarty JA, Cheng KJ, Costerton JW. Is there a role for lactobacilli in prevention of urogenital and intestinal infections? Clin Microbiol Rev 1990; 3: 335-344. 